\title{
Physiological quality, anatomy and histochemistry during the development of carrot seeds (Daucus carota L.)
}

\author{
Qualidade fisiológica, anatomia e histoquímica durante o desenvolvimento \\ de sementes de cenoura (Daucus carota L.)
}

\author{
Rafaela Marques de Miranda ${ }^{1}$, Denise Cunha Fernandes dos Santos Dias ${ }^{2 \star}$, Edgard Augusto de Toledo Picoli ${ }^{3}$, \\ Patrícia Pereira da Silva ${ }^{4}$, Warley Marcos Nascimento ${ }^{4}$
}

1Prefeitura Municipal de Ouro Preto, Secretaria de Agropecuária, Ouro Preto, MG, Brasil

¿Universidade Federal de Viçosa/UFV, Departamento de Fitotecnia, Viçosa, MG, Brasil

${ }^{3}$ Universidade Federal de Viçosa/UFV, Departamento de Biologia Vegetal, Viçosa, MG, Brasil

${ }^{4}$ Empresa Brasileira de Pesquisa Agropecuária/Embrapa, Embrapa Hortaliças, Brasília, DF, Brasil

${ }^{*}$ Corresponding author: dcunhadias@gmail.com

Received in March 10, 2016 and approved in October 31, 2016

\begin{abstract}
The adequate time for carrot seed harvest influences its physiological quality. The objective of this study was to evaluate physiological, anatomical and histochemical changes in carrot seeds harvested at different stages of development and to establish the most appropriate harvest time. Secondary umbels were harvested at 14,21,28, 35, 42, 49, 56 and 63 days after anthesis (DAA). For seed anatomical and histochemical characterization, sections were stained with Toluidine blue stain, Xylidine Ponceau, Lugol's iodine, Sudan Black B and submitted to polarized light. Seed moisture content, seed dry matter, germination, first count, emergence percentage and emergence speed index of seedlings were evaluated. Cultivar Brasília carrot seeds at 14 DAA are in cell division and expansion. In addition, as lipids were identified in the endosperm, despite the seed low dry matter. At 21 DAA, reserve substances such as protein and starch were also identified. Along the seed development process, deposition of lignin occurs in the endocarp cells, and this collapsed lignified layer represents the resistance layer of the seeds. Physiological maturity, represented by the maximum dry matter accumulation, occurs at 35 DAA, with the endosperm occupying almost all volume of seeds, the embryo occupying a small cylindrical region and the integument showing a single layer of cells. At this time, the seeds presented $56 \%$ moisture content and the color of the pericarp is green-yellow. Maximum seed germination and vigor occurred at 30 DAA, just before physiological maturity was reached (35 DAA). Thus, the ideal time to harvest the seeds of cultivar Brasília is from $30 \mathrm{DAA}$, where the seeds have maximum physiological quality.
\end{abstract}

Index terms: Maturity; harvest; reserve substances; germination; vigor.

\begin{abstract}
RESUMO
A colheita das sementes de cenoura no momento adequado tem reflexos diretos sobre a sua qualidade fisiológica. O objetivo do trabalho foi avaliar as alterações fisiológicas, anatômicas e histoquímicas em sementes de cenoura colhidas em diferentes estádios de desenvolvimento e estabelecer a época mais adequada para a colheita. Foram colhidas umbelas secundárias aos 14, 21, 28, 35, 42, 49 , 56 e 63 dias após antese (DAA). Para a caracterização anatômica e histoquímica os cortes foram corados com Azul de toluidina, Xylidine Ponceau, Lugol, Sudan black B e submetidos à luz polarizada. As sementes foram submetidas aos seguintes testes: grau de umidade, matéria seca, germinação, primeira contagem, porcentagem e índice de velocidade de emergência de plântulas. Sementes de cenoura 'Brasília', aos 14 DAA, encontram-se em divisão e expansão celular e apesar da reduzida matéria seca, lipídios foram identificados no endosperma. Aos 21 DAA, além de lipídios, proteínas e amido foram identificados. A maturidade fisiológica das sementes ocorreu aos 35 DAA, com o endosperma ocupando praticamente todo volume das sementes, o embrião ocupando uma pequena região cilíndrica e o tegumento apresentando uma única camada de células. Nesta fase, as sementes apresentaram $56 \%$ de grau de umidade e a coloração do pericarpo era verde-amarelo. A máxima germinação e vigor das sementes ocorreu aos 30 DAA, um pouco antes da maturidade fisiológica (35 DAA). Portanto, a época ideal para a colheita das sementes de cenoura 'Brasília' é a partir de 30 DAA, quando as sementes apresentam máxima qualidade fisiológica.
\end{abstract}

Termos para indexação: Maturação; colheita; substâncias de reserve; germinação; vigor.

\section{INTRODUCTION}

Carrot (Daucus carota L.) is a vegetable of great economic importance, being among the ten most produced ones in Brazil. It belongs to the Apiaceae family and the plant has an indeterminate growth and a composed umbel- type inflorescence. The fruit is a di-achene, and at maturity each achene gives origin to a seed (Viggiano, 1990).

When induced to flowering, the plant moves from the vegetative to the reproductive phases, giving a rod or floral tassel ending in an umbel-type inflorescence called central or primary umbel. From this one, there are branches ending in 
secondary umbels from which new branches or tertiary umbels rise. Umbels of different orders have flowering, anthesis and maturity of seeds in chronologically different times, starting with the primary umbel, followed by the secondary ones and so on (Hawthorn; Toole; Toole, 1962). Secondary umbels are responsible for most of the yield due to the number of umbels per plant and seed size (Panayotov, 2010). Nascimento (1991) has reported that primary, secondary and tertiary umbels contribute $11.0 \%, 58.0 \%$ and $31.0 \%$, respectively, of the total seed yield from cultivar Brasília. Flowering within each umbel is not uniform (Carvalho et al., 2014), resulting in seeds with different maturity levels at harvest. Nascimento (1991) has observed that germination and seed vigor decreased with the increase of the order of umbels.

Considering that the establishment of carrot crops must be done by direct sowing, the use of high physiological quality and health seeds is critical to an adequate and uniform stand, which will have positive effects on plant growth and hence on the final production and standardization of the product harvested.

The harvest at the appropriate time minimizes the effects of deterioration caused by the stay of seeds in the field, and reduces the ratio of unripe seeds in the lot due to early harvest (Vidigal et al., 2009; 2011). Thus, studies related to the seed maturity process are critical to establish the point at which the seeds reach the maximum physiological quality and determine the optimal harvest time.

Physiological maturity has been characterized by some authors as the moment when the seeds reach maximum dry matter accumulation, showing that translocation of assimilates from the plant to the seed has ceased (Harrington, 1972; Tekrony; Egly; Phillips, 1980; Demir; Ellis, 1992). At this point, seed deterioration is minimal and may or may not coincide with the maximum physiological quality, i.e., maximum germination and vigor.

Gray, Ward and Steckel (1984) have reported that the maximum dry matter content of carrot seeds occurred at 35 DAA (days after anthesis) when the pericarp was green and less than $50 \%$ of the seeds were viable. Seeds acquired ability to germinate between 21 and 35 DAA and the germination percentage gradually increased up to 79DAA. For Nascimento, Vieira and Alvares (2003), the maximum physiological quality of carrot seeds in cultivar Alvorada was reached between 49 and 56 DAA, with moisture content near 10\%.

Physical characteristics such as seed color have been used as a tool to determine the best time for harvest. George (1985) and Rubatzky, Quiros and Simon (1999) have observed that carrot seeds are brown when ripe. Perleberg et al. (2001) observed that seeds with lower chlorophyll content in the pericarp had higher germination.
In all of these studies on carrot seed maturation, anatomical and histochemical changes that occur from egg fertilization to harvest were not evaluated. According to Panayotov (2010), carrot seeds from secondary umbels show at maturity approximately $14 \%$ protein, $11 \%$ sugar and $17 \%$ lipids. These data were obtained from chemical analyses and there was no information on the cellular localization of these reserves and histochemical characterization during the different stages of seed development.

Thus, it is important to relate physical, anatomical and histochemical characteristics, monitoring the reserves accumulated during seed development, with physiological quality, especially for cultivars of great interest to farmers, such as 'Brasilia'.

Given the above, the objective of this research was to associate histochemical, physical and physiological changes occurring during the carrot seed maturation process in cultivar Brasília, and determine the most appropriate time for harvest aimed at the yield of high physiological quality seeds.

\section{MATERIAL AND METHODS}

Carrot seeds from cultivar Brasília were produced in the field in the experimental area of 'Embrapa Hortaliças (EMBRAPA - Empresa Brasileira de Pesquisa Agropecuária)' in Brasília, DF, Brazil, at 1,004 m altitude, with the following coordinates: $15^{\circ} 55^{\prime} 46,58^{\prime \prime} \mathrm{S}$ and 4808'26,84'”W.

In a first step, a field was established for the production of roots and sowing was done on November 20, 2012. Before sowing, the soil was fertilized based on the results of soil analysis, employing160 g/m² of NPK 04-30-16 + B and Zn. Topdressing was done 35 days after sowing with ammonium sulfate at a dose of $40 \mathrm{~kg} / \mathrm{ha}$. At 33 days after sowing, thinning was done, leaving one plant every $10 \mathrm{~cm}$. Cultivations were done according to the recommendations for carrot crops. The roots were harvested on $02 / 27 / 2013$, selecting the ones that were cylindrical, smooth, length between $16.0-22.0 \mathrm{~cm}$ and a diameter of approximately $3.0 \mathrm{~cm}$.

On the day after the harvest, the roots were vernalized in cold storage at $6{ }^{\circ} \mathrm{C}$ and $90 \%$ air relative humidity for 50 days. After this period, the roots were sowed in the field on 04/18/2013 using the planting system in 30-cm high windrows. The soil was fertilised according to soil analysis results. The field was managed according to basic recommendations for the production of carrot seeds (Silva et al., 2014). Topdressing was done with ammonium sulfate at a $15 \mathrm{~g} /$ linear meter dose when it began to flourish (Silva et al., 2014) in June 2013. Umbels were marked at the time of anthesis. 
Ten secondary umbels were randomly chosen from different plants in eight developmental stages: at 14,21,28,35, 42, 49, 56 and 63 days after anthesis (DAA). After harvesting the umbels, the seeds were threshed and cleaned manually. Seed moisture content (A) was determined in two replicates of 200 seeds by the oven method at $105 \pm 3{ }^{\circ} \mathrm{C}$ for 24 hours (Brasil, 2009). The results were expressed as percentage (wet basis).

The seeds obtained at each harvest time were then weighed (Wi) and dried in an oven with air circulation at $30{ }^{\circ} \mathrm{C}$ until reaching moisture content of around $12 \%$. During drying, the seeds were removed from the oven periodically and weighed. Thus, seed moisture content of $12 \%$ (B) was monitored by means of successive weighings, until the required weight value (Wf) was obtained according to the following equation (Hampton; TeKrony, 1995):

$\mathrm{Wf}=100-\mathrm{A} / 100-\mathrm{B} \times \mathrm{Wi}$,

where $\mathrm{Wf}=$ final weight of seeds $(\mathrm{g}), \mathrm{A}=$ initial seed moisture content, $\mathrm{B}=$ required seed moisture content $(12 \%)$, and $\mathrm{Wi}=$ initial weight of seeds $(\mathrm{g})$.

After drying, the seeds were submitted to the following evaluations at Seed Laboratory at the Federal University of Viçosa, in the Brazilian municipality of Viçosa, MG:

Seed dry matter: consisted in the average final weight of the seeds after drying at $105 \pm 3^{\circ} \mathrm{C}$ for 24 hours, as described above. The results were expressed in $\mathrm{mg} / \mathrm{seed}$.

Germination: conducted with four replicates of 50 seeds distributed on two sheets of towel paper moistened with distilled water at a ratio of 2.5 times the weight of the dry paper in Gerbox ${ }^{\circledR}$-type plastic boxes. The boxes were kept in a germination chamber at $20^{\circ} \mathrm{C}$ to determine the percentage of normal seedlings on the seventh and fourteenth days after seeding (Brasil, 2009).

Germination first count: conducted together with the germination test, consisting of the percentage of normal seedlings at seven days after sowing.

Emergence speed index (ESI) and emergence percentage of seedlings: conducted in a greenhouse, with sowing carried out in trays containing soil and sand at the ratio 1:1, using four subsamples of 50 seeds. Daily counts of the number of emerged seedlings were performed until stabilization of the stand that occurred on the fourteenth day after sowing. ESI, according to Maguire (1962), and the percentage of emerged seedlings were calculated.

Experimental design and statistical analysis: a completely randomized design with four replications was used. Data were subjected to analysis of variance and regression analysis, and estimates of regression parameters were analyzed by the t-test at 5\% probability. Analyses were performed using the SAS (Statistical Analysis System) software suite (Delwiche; Slaughter, 2003).

The seeds were also subjected to anatomical and histochemical analyses carried out at Plant Anatomy Laboratory of the Plant Biology Department at the Federal University of Viçosa. The seeds obtained in each harvest time were fixed in FAA70 (formaldehyde: acetic acid: ethyl alcohol) for $72 \mathrm{~h}$ and stored in $70 \%$ ethanol (Johansen, 1940). Later, they were dehydrated in an increasing ethanol series and embedded in methacrylate (Historesin - Leica) according to the manufacturer's recommendations. The material was sectioned in cross-sections and longitudinal sections in a $5-\mu \mathrm{m}$ thick rotating microtome. For anatomic characterization, the sections were stained with Toluidine blue (O'Brien; Feder; McCully, 1964) and assembled under a cover slip with a synthetic resin $\left(\right.$ Permount ${ }^{\mathrm{TM}}$ ). For histochemical analyses, the sections were subjected to the following reagents/dyes: double Toluidine blue stain with reagent Lugol's Iodine (also known as Lugol's Solution) for detection of starch (Johansen, 1940); Xylidine ponceau (XP) for detection of total protein (Vidal, 1977). The cross sections were also subjected to polarized light for detection of starch (Johansen, 1940).

For detection of lipids, the seeds fixed in FAA70 had cross-sections at $40 \mu \mathrm{m}$ in cryomicrotome and the samples were transferred and stored in sucrose solution. The sections were stained with Sudan Black B (Pearse, 1972).

Observing and obtaining images (anatomical/ structural and histochemical parts) were held in a photomicroscope (model AX70 TRF, Olympus Optical, Tokyo, Japan) with the U-PHOTO system, coupled to a digital camera (model AxionCan, Carl Zeiss AG, Jena, Germany) and a microcomputer.

\section{RESULTS AND DISCUSSION}

Figure 1 shows the carrot seeds, cultivar Brasília, in each harvest time. At 14 DAA the seeds had become light green, between 21 and 28 DAA the seeds were green, at 35 DAA they were yellowish green, and from 42 DAA they were completely brown.

Carrot seeds are surrounded by the pericarp made up of epicarp, mesocarp and endocarp. These parts are partially joined to the seed (Bercu; Broascã, 2012). At 14 DAA it is possible to identify each of these layers of pericarp cells (Figures 2A and C). At this stage, the seeds in early development do not occupy the entire space defined by the pericarp (Figure 2A), the integument shows a single layer of cells (Figure 2A, arrow) and the endosperm is in the phase of cell division and expansion. The embryo, in early 
formation, occupies a small volume of the seed and the suspensory can be recognized in it, facing the micropylar area, and the embryo itself in the most distal portion (Figures 2B and D).

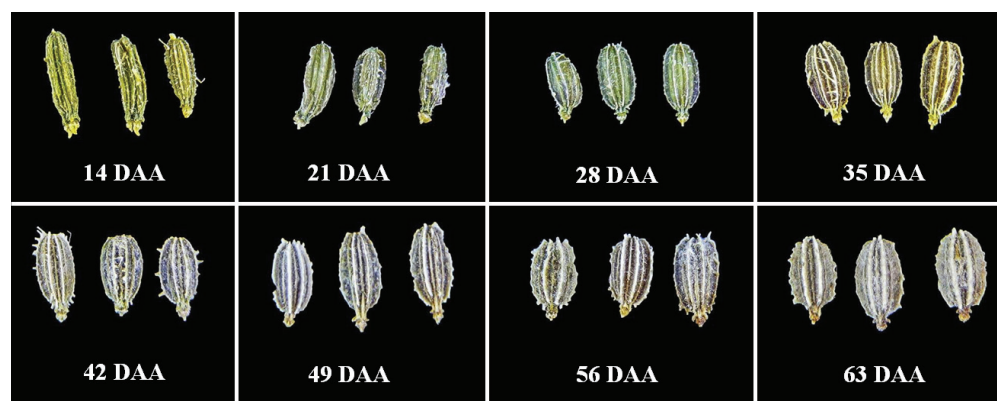

Figure 1: Carrot seeds, cultivar Brasília, harvested at different maturity stages (DAA).

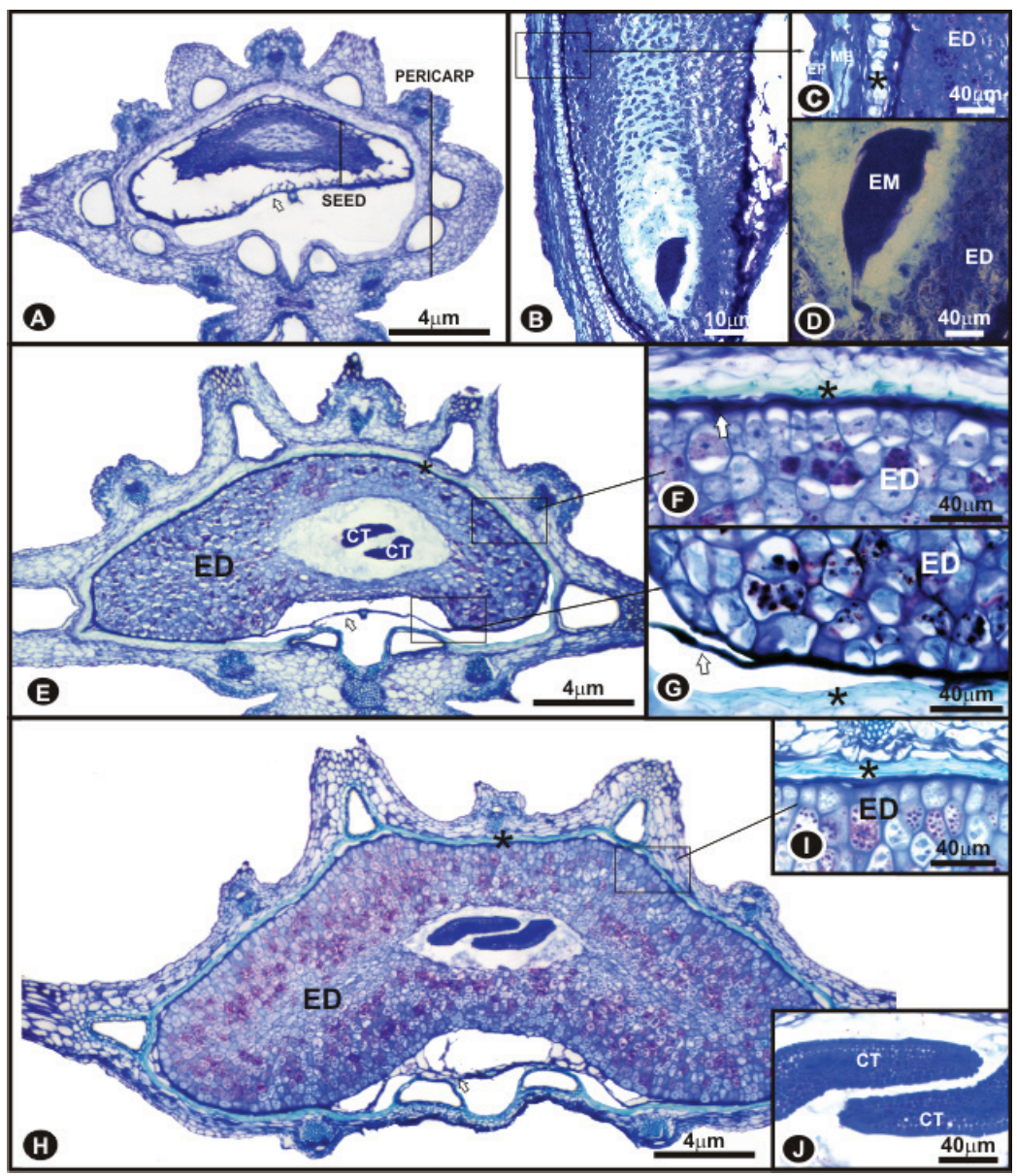

Figure 2: Carrot seeds sections (stained with Toluidine blue) at different stages of development: 14 DAA (A-D), 21 $\mathrm{DAA}(\mathrm{E}-\mathrm{G}), 28 \mathrm{DAA}(\mathrm{H}-\mathrm{J})$. View of the seeds in the cross-section at 14 DAA (A), $21 \mathrm{DAA}(\mathrm{E}), 28 \mathrm{DAA}(\mathrm{H})$. View of the seeds $s$ in the longitudinal section at 14 DAA (B). View of the pericarp and endosperm in the longitudinal section at 14 DAA (C). View of the embryo in the longitudinal section at 14 DAA (D). View of the endocarp lignification in cross section at 21 DAA (F) and 28 DAA (I). View of the seed integument at 21 DAA (G). View of the cotyledons in cross section at 28 DAA (J). CT, cotyledon; ED, endosperm; EM, embryo; EP, epicarp, ME, mesocarp; arrow, integument; (*), endocarp. 
At 21 DAA the process of lignin deposition in the endocarp cell walls begins (Figures 2E and F). The endosperm remains in cell division and expansion, and the embryo, more developed than in the previous stage, has two obvious cotyledons (Figure 2E). The nonmultiplicative integument has a single layer of cells to the ripe seeds. At $28 \mathrm{DAA}$, the endosperm has become well developed (Figure 2H) and the deposition of lignin in the endocarp cells is intensified, where the cells are collapsed and lignified (Figure 2I), and this is the seeds resistance layer. From 28 to 35 DAA, anatomical changes hardly occur in the seeds, which can be evidenced by the comparison of Figures $2 \mathrm{H}$ and $3 \mathrm{~A}$.

At 35 DAA, the endosperm occupies virtually all seed volume, except for a small cylindrical area occupied by the embryo (Figure 3A). The embryo presents a straight and cylindered hypocotyl-radicle axis, undifferentiated plumule and cotyledons, protoderms and distinguishable procambium (Figures 3A, C, D and E). At 63 DAA, the pericarp is partially collapsed (Figures $3 \mathrm{~F}$ and $3 \mathrm{G}$ ).
At 14 DAA, the seeds dry matter was low (less than $0.5 \mathrm{mg} / \mathrm{seed}$ ) and the seeds were light green (Figure 1). The presence of starch grains was not identified by the double Toluidine blue stain and Lugol's iodine or with polarized light (Figures 4A and B).

From 14 DAA, increase in dry matter content is observed and by histochemical analyses it was possible to observe the deposition of reserve compounds, mainly in the endosperm. At $21 \mathrm{DAA}$, it is already possible to see the presence of small and specific starch grains dispersed in the endosperm cells (Figures 4C and D), which have become more evident from $28 \mathrm{DAA}$ (Figures $4 \mathrm{E}$ and F), thus remaining until the end of seed development (Figures 4G, $\mathrm{H}, \mathrm{I}$ and $\mathrm{J}$ ). Proteins are accumulated in protein bodies and can be observed in the parenchyma cells of the endosperm from 21 DAA (Figure 5C). At 28 DAA, large amounts of proteinaceous material dispersed throughout the cells cytoplasm can be observed (Figure 5E), and the same pattern of deposition is maintained until the end of the seed maturity process (Figures $5 \mathrm{G}$ and I).

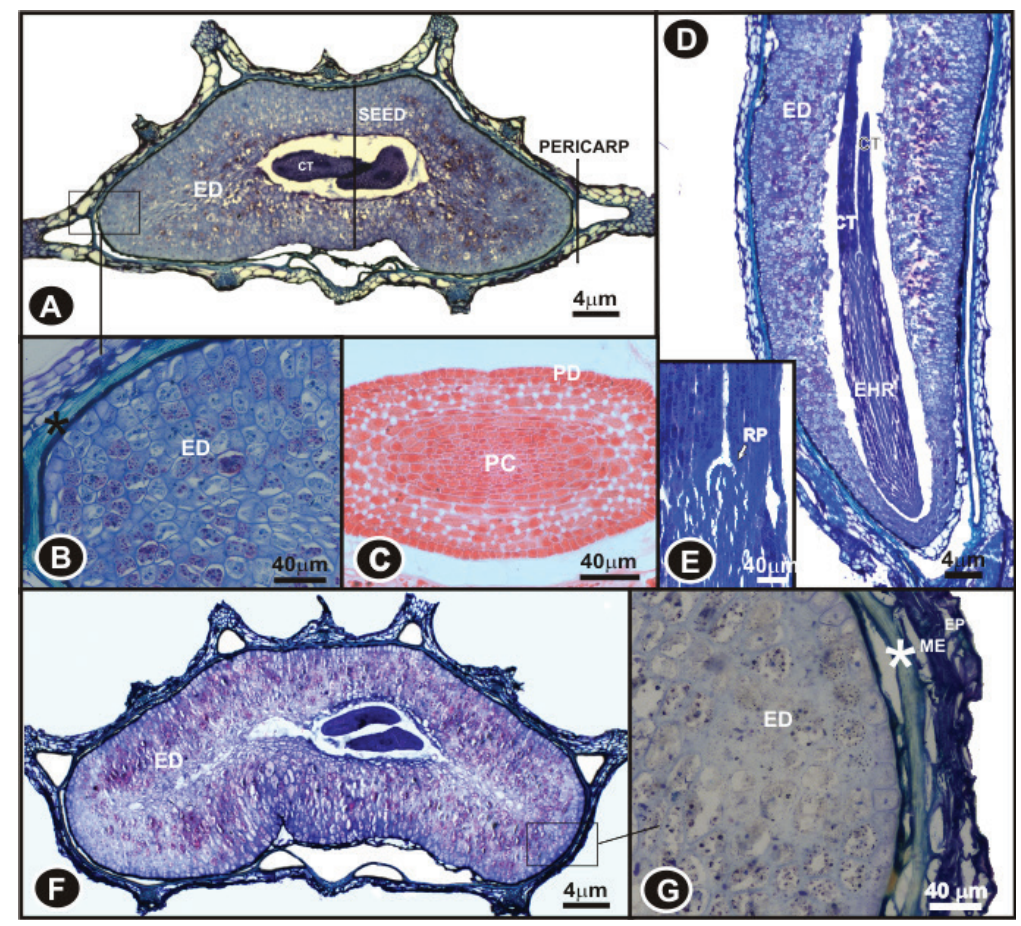

Figure 3: Cross-sections of carrot seeds harvested at 35 DAA stained with Toluidine blue (A and B) and with Xylidine ponceau (XP) (C). Longitudinal sections of carrot seeds harvested at 35 DAA stained with Toluidine blue ( $D$ and E). Cross-sections of carrot seeds harvested at 63 DAA stained with Toluidine blue ( $F$ and G). General view of the seed in cross-section (A) and longitudinal section (D). View of the endocarp lignification (B). View of the embryo in cross-section (C) and longitudinal section (E). General view of the seed in cross-section at 63 DAA (F). View of the collapsed pericarp (G). CT, cotyledon; ED, endosperm; HRA, hypocotyl-radicle axis; EP, epicarp; ME, mesocarp; PC, procambium; PD, protoderm; PA, plumule area; $\left(^{*}\right)$ endocarp. 


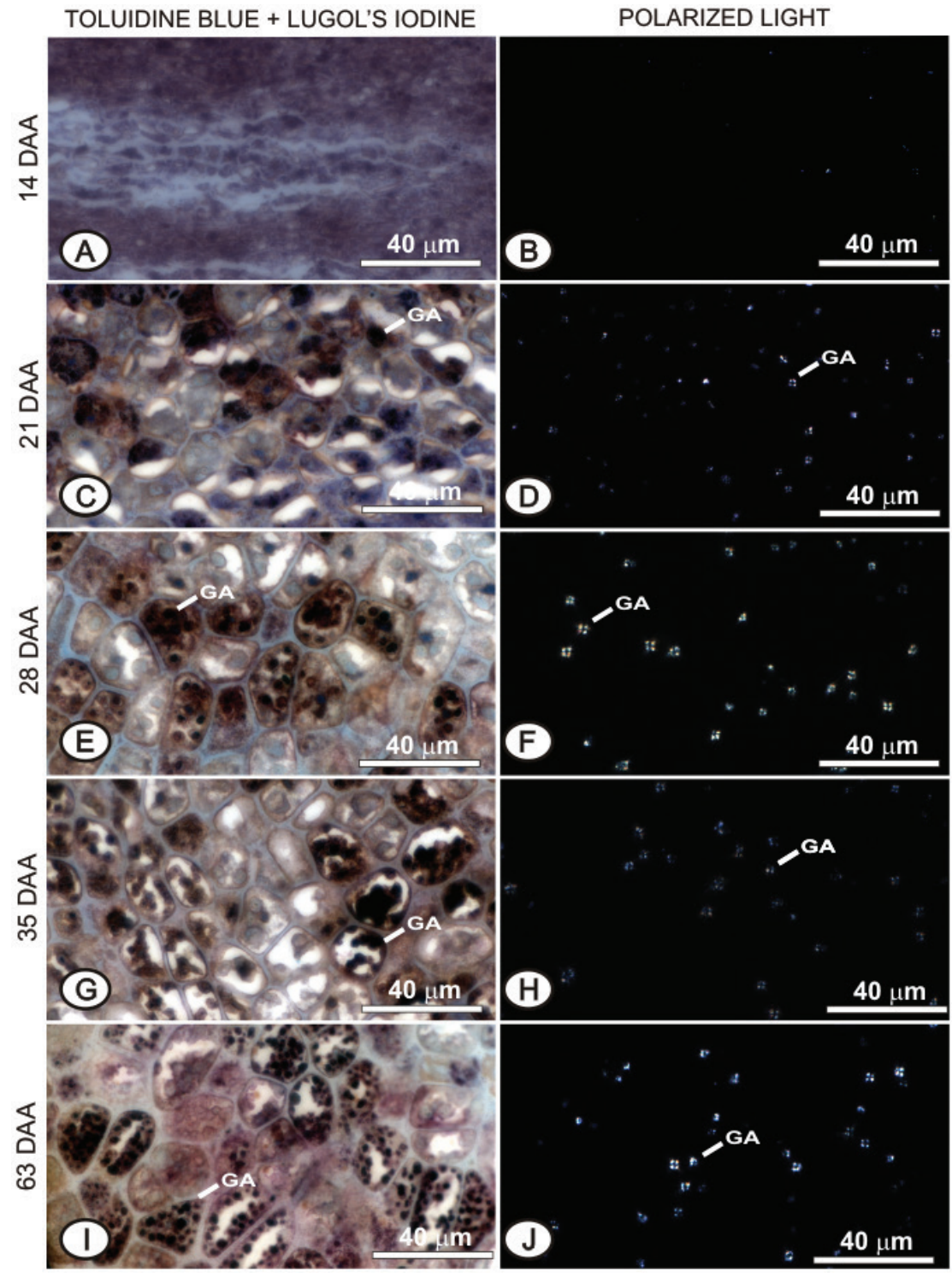

Figure 4: Cross-sections of carrot seed endosperm collected at 14 DAA (A and B), at 21 DAA (C and D), at 28 DAA ( $E$ and $F)$, at 35 DAA ( $G$ and $H$ ) and at 63 DAA (I and J). Sections stained with Toluidine blue plus reagent Lugol's iodine to identify starch ( $A, C, E, G$ and $I)$ and sections subjected to polarized light to identify starch (B, D, F, H and J). SG, starch grain.

Carrot seeds have an endosperm rich in oil (Corner, 1976), as well as other seeds of the Apiaceae family (Ross; Murphy, 1992). Thus, lipids are the main source of reserve in carrot seeds and are present in the early stages of development, at 14 DAA (Figure 5B), remaining up to 63 DAA (Figure 5J). Lipids are accumulated in the endosperm cells in lipidic bodies (Graham, 2008). Part of the cell cytoplasm where lipidic bodies are located (not visible by light microscopy) reacts with the dye Sudan
Black B (Figures 5B, D, F, H and J), and lipidic droplets are formed during the sectioning of the material. According to Dutta et al. (1991), a rapid increase in lipid deposition begins about 21 days after pollination and continues until 35 days after pollination. At 63 DAA there is no alterations in the lipids content in the seeds (Figure 5J), but it was observed a reduction in the protein bodies (Figure 5I) indicating an initial process of proteins degradation in the seeds harvested later. 


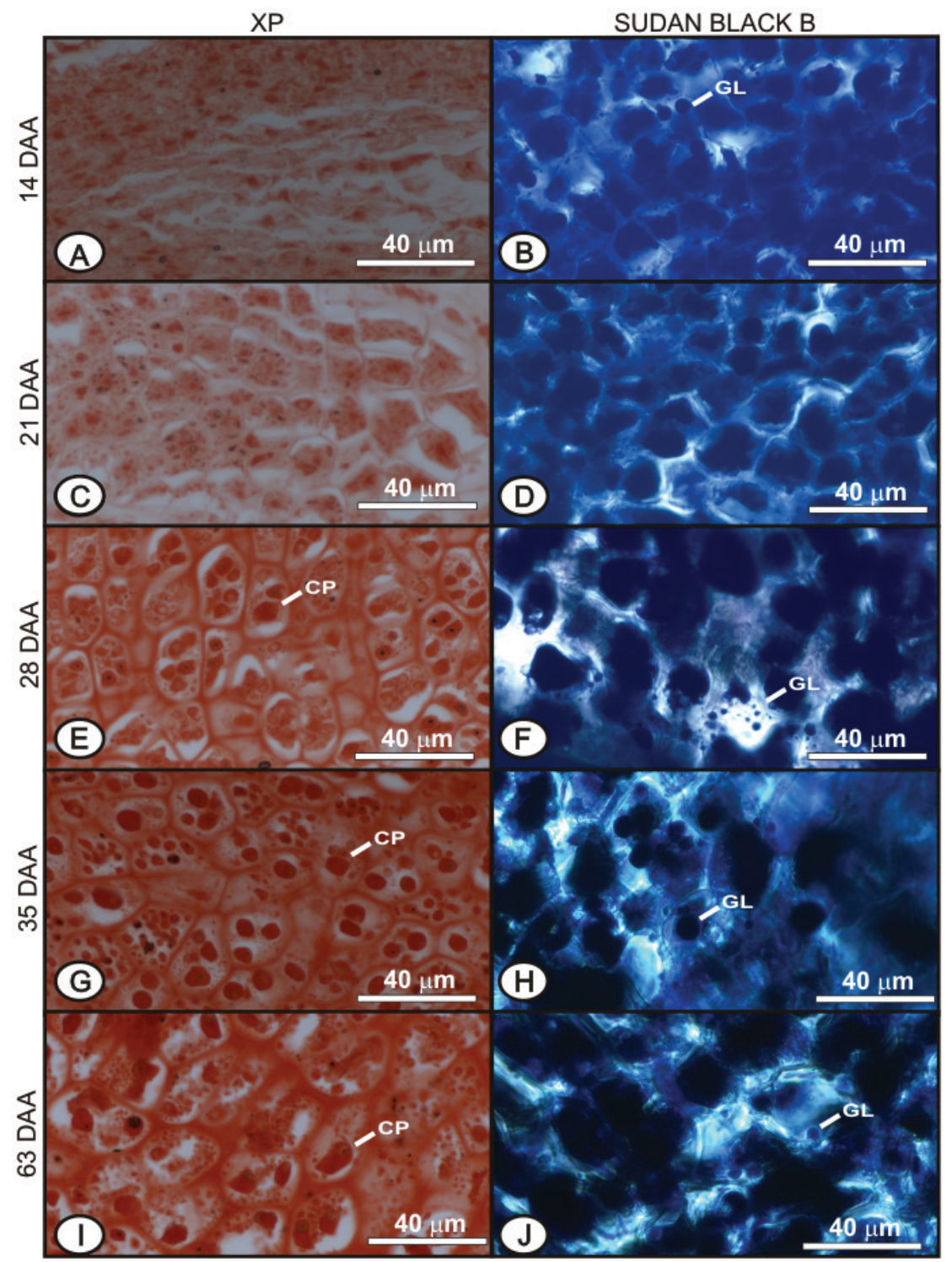

Figure 5: Cross-sections of carrot seed endosperm collected at 14 DAA (A and B), at 21 DAA (C and D), at 28 DAA (E and F), at 35 DAA (G and $H$ ) and at 63 DAA (I and J). Sections stained with Xylidine Ponceau (XP) for protein identification ( $A, C, E, G$ and $I$ ) and Sudan Black B for identification of lipids ( $B, D, F, H$ and J). PB, protein body and LD, lipidic droplet.

There has been a progressive increase in dry matter over the course of the development process until about 35 DAA (Figure 6A), stabilizing thereafter, indicating no more translocation of assimilates from the plant to the seeds. Thus, it can be observed that the seeds reached physiological maturity at 35 DAA, which was also observed by Gray, Ward and Steckel (1984). As for Nascimento, Vieira and Alvares (2003), they found that the physiological maturity of carrot seeds 'Alvorada', belonging to the Brasília group, occurred between
49 and 56 DAA in the conditions of Brasília, DF. Seeds with higher germination percentage and emergence speed index were obtained from 50 DAA (Tucker; Gray, 1986).

At 35 DAA, that is, when physiologically ripe, carrot seeds were yellowish green (Figure 1). According to George (1985) and Rubatzky, Quiros and Simon (1999), carrot seeds reach the point of harvest when they become brown and are therefore ripe, which in the present study occurred from 42 DAA (Figure 1). 

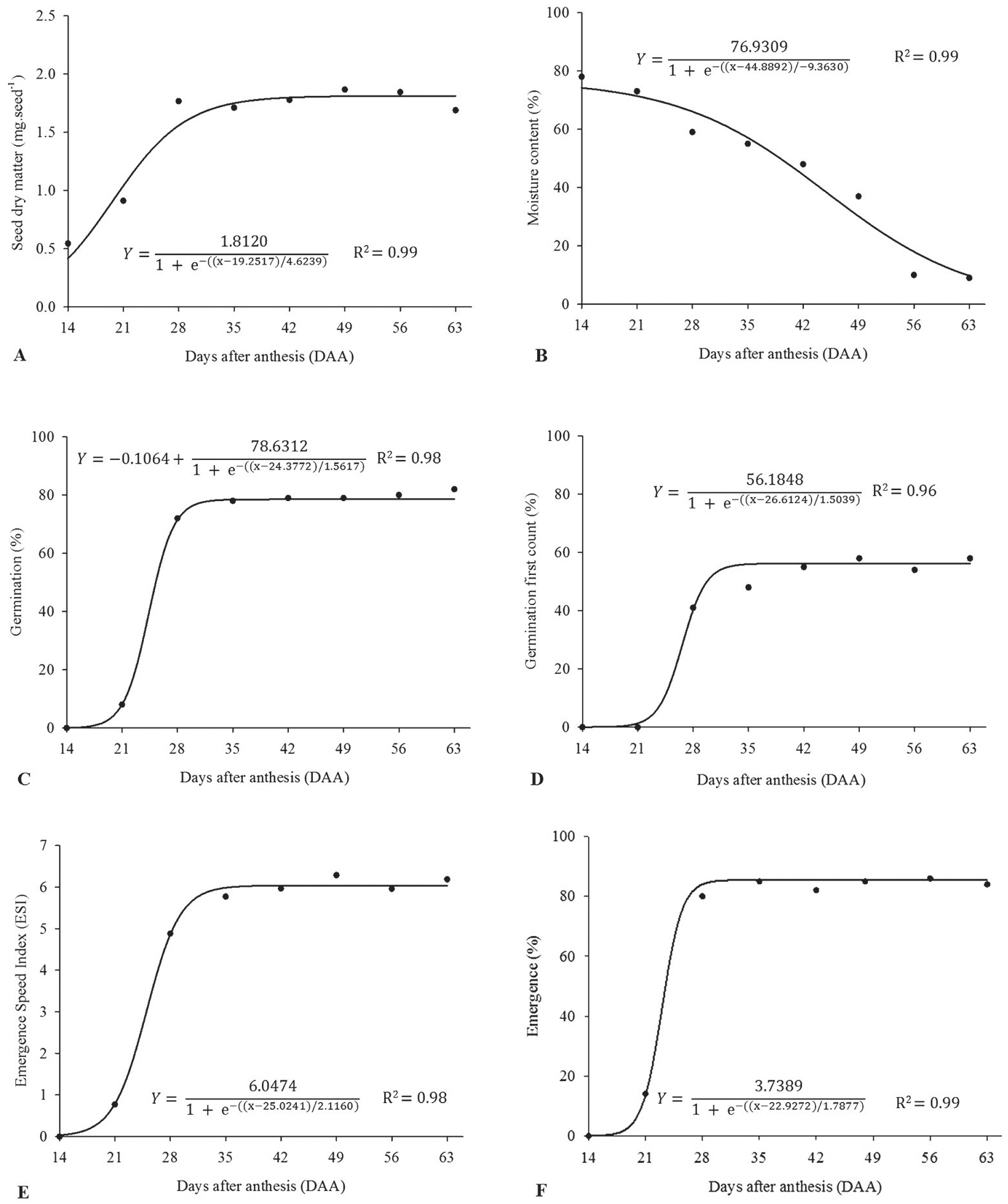

Figure 6: Changes in seed dry matter (A), moisture content (B), germination (C), germination first count (D), emergence speed index (ESI) (E) and emergence percentage of seedlings (F) of carrot seeds, cultivar Brasília, harvested at different stages of development (DAA). 
During the maturity process, as there is the accumulation of dry matter, water is replaced by reserve substances that are synthesized by developing seeds. Therefore, in the early stage of development, at 14 DAA, seeds moisture content is high, close to $80 \%$ (Figure 6B), but it will slowly and continuously decrease throughout the development process, so that at $35 \mathrm{DAA}$, when the maximum dry matter content is reached, the seeds presented moisture content of about $56 \%$, which is still relatively high.

Carrot seeds germination was null at 14 DAA (Figure 6C). At this point, dry matter content was low (0.5 $\mathrm{mg} / \mathrm{seed}$ ), with the seeds at the start of formation (Figures $2 \mathrm{~A}, \mathrm{~B}, \mathrm{C}$ and D), so that the very small embryo had not germinate, and the endosperm had no significant amount of reserves yet to be mobilized during germination (Figures 4A, 4B and 5A). According to Bewley et al. (2013), after fertilization there is a period when formation of the seed structure occurs as a result of cell division, expansion and differentiation, as observed in Figures 2 and 3. During this phase of histodifferentiation, there is an increase in the length and width of seeds, and the moisture content remains consistent and high, as shown in Figure 6A. Carrot seeds acquired the ability to germinate as of 21 DAA (Figure 6C), which was also observed by Gray, Ward and Steckel (1984), but germination percentage was low. So, at 21 DAA, despite the small increase in dry weight, this content was not enough for complete germination (normal seedling). This was probably the cause of low seed germination. At this stage, it was seen that the embryo was already slightly more developed (Figure 2E) and reserve substances were already present in the endosperm (Figures 4C, D and 5C, D).

It would be possible that the more immature seeds, such as the ones harvested at 14 and 21 DAA, had not acquired desiccation tolerance yet, and this could be the cause of lower germination. However, it is important to consider that during the maturation process, cells may be more sensitive to speed of dehydration than to reduction in the amount of water absorbed (Kermode, 1997; MarcosFilho, 2016). Gradual loss of water may permit greater activation of protective mechanisms that provide tolerance to cell imbalances caused by dehydration in comparison to rapid drying. In our experiment, carrot seeds harvested at 14 and 21 DAA were dried slowly at $30^{\circ} \mathrm{C}$ for about 72 hours to avoid the consequences of dehydration. Although we did not use dried and fresh seeds in this study to compare the effects of drying, previous investigations with sweet pepper seeds (Vidigal et al., 2009) comparing fresh and dried seeds (no published data) have shown low germination for both at early stages of maturation. Thus, we concluded that low dry matter content and embryo immaturity were responsible for lower germination (normal seedlings, not radicle protrusion). Some investigations carried out by other authors, such as Demir and Ellis (1992) in tomato, Demir (1997) in okra and Contreras et al. (2008) in lettuce showed that there was no difference in the germination of fresh and dried seeds even at early harvest. According to Contreras et al. (2008), lettuce seed desiccation in the early stages of seed development did not affect germination of fresh and dried seeds; full germination capacity of these seeds coincided with the time at which embryo elongation was completed and occupied part of the space initially filled by the endosperm. These results are compatible with our results of anatomical and histochemical analysis (Figures 3, 4 and 5).

From 21 DAA, germination increases exponentially, reaching maximum value at about 30 DAA. It was found that there were practically no expressive anatomical changes in the seeds from 28 to 35 DAA (Figures $2 \mathrm{H}$ and $3 \mathrm{~A}$ ), close to the maximum point of germination. Embryo elongation and endosperm formation were practically complete. Histochemical changes show large amounts of starch (Figure 4E and F) and proteins (Figure 5E) in endosperm cells at 28 DAA, indicating that reserves became abundant for seed germination. From 30 DAA, germination was practically maintained until 63 DAA (Figure 6C). Thus, it can be said that the seeds had reached maximum germination and vigor at 30 DAA just before the stage of maximum dry matter content (35 DAA), in agreement with the results obtained by Gray and Steckel (1982). Similar results were observed in tests of germination first count, ESI and emergence percentage of seedling (Figures 6D, 6E and 6F, respectively), where, in general, maximum values were obtained at approximately 30 DAA, practically stabilizing thereafter. Thus, considering these parameters, seed vigor was maximum at about 30 DAA and the values obtained at this harvest time were similar to those observed in the subsequent harvests until 63 DAA.

According to Marcos-Filho (2016), the environment can influence seed development and maturation by altering the ability of the seed to accumulate dry matter and, consequently, seed germination and vigor. The rate of seed development is generally uniform in different environments because adjustments in the number of seeds produced by the plant maintain a relatively constant supply of assimilates to the seeds. Stress such as water deficits, low and high temperature, and nutrient deprivation can occur any time during seed development. The duration of the stress is also important, as well as the stage of development in 
which it occurs. Therefore, stress conditions during seed development may vary in importance, depending on the time they occur and their duration. Cell division and elongation after fertilization determine seed size, reserve storage capacity, and, consequently, physiological quality, which may be reduced by water and heat stress. In our experiment, we provided conditions for adequate plant development and yield by using suitable agricultural practices (plant nutrition, water supply) that allow production of quality seeds. As the environmental conditions were suitable, they did not affect the seed filling period, which was at a maximum level at 35 DAA. The physiological quality of the seeds was also not affected, and maximum germination and vigor occurred around 30 DAA, as observed by Gray and Steckel (1982). Since one of the critical phases of seed development is the period of transfer of dry matter to seeds, crop practices should be important to ensure maximum accumulation of reserves in the seeds, which is reflected in seed quality characteristics. Therefore, we should consider that the ideal time to harvest carrot seeds is from 30 DAA because the seed germination and vigor were maximum, although the values did not reduce significantly until 63 DAA. However, depending on environmental condition, especially under less favorable conditions, delay in harvest may cause a decline in physiological quality or natural shattering of seeds. High temperatures and relative humidity after physiological maturity predispose seeds to deterioration process in the field.

In summary, it is seen that the maximum values of germination and vigor of carrot seeds occur from 30 DAA and continue until 63 DAA (Figures 6C, D, E, F), i.e., just before physiological maturity is achieved (about 35 DAA), when the seeds dry matter was maximum (Figure 6A). This information is in accordance with data obtained by Tekrony and Egli (1997), in a study with potherbs of dried and fleshy fruits under wide variations in environment, where the maximum physiological quality of dried fruit seeds occurred before or coinciding with the moment when the dry matter content was maximum. This was not observed in species whose seeds are contained in fleshy fruits.

Thus, to obtain maximum physiological quality the appropriate time for the harvest of carrot seeds of cultivar Brasília is at 30 DAA. At this stage of development, the seeds are yellowish green and have $56 \%$ of moisture content. At physiological maturity, the endosperm occupies practically the entire volume of the seeds, where reserve substances such as lipids, proteins and carbohydrates are stored in the form of starch. The embryo occupies a small cylindrical area, the integument shows a single layer of cells, and the lignified endocarp is the resistance layer of carrot seeds.

\section{CONCLUSIONS}

Carrot seeds cultivar Brasília, under the conditions Brasília, DF, Brazil, at 14 DAA, are in the cell division and expansion phases and, despite the low dry matter, reserve substances such as lipids were identified in the endosperm. At 21 DAA, not only lipids, but also proteins and starch were identified in the endosperm. At 28 DAA, the endosperm was completely developed, and from 28 to 35 DAA, anatomical changes hardly occur in the seeds. Physiological maturity, represented by maximum dry matter, occurs at $35 \mathrm{DAA}$, when the seed moisture content is about $56 \%$ and the color of the pericarp is yellowish green. At physiological maturity, the endosperm occupies practically the entire volume of seeds, except for a small cylindrical area occupied by the embryo, and the integument has a single layer of cells. Maximum germination and vigor are reached at about $30 \mathrm{DAA}$ and continue until 63 DAA. Therefore, the optimal time for harvesting carrot seeds is $30 \mathrm{DAA}$, when the seeds have maximum physiological quality.

\section{REFERENCES}

BERCU, R.; BROASCĂ, L. Comparative histoanatomical aspects of the fruit of some Apiaceae lindl. fruit used for therapeutic purposes. Analele Societatii Nationale de Biologie Celulara, 17(1):265-270, 2012.

BEWLEY,J. D. et al. Seeds: Physiology of development, germination and dormancy. 3. ed. New York: Springer. 2013. 392p.

BRASIL. MAPA - Ministério da Agricultura, Pecuária e Abastecimento. Secretaria de Defesa Agropecuária. Regras para análise de sementes. Brasília: MAPA/ACS, 2009. 395p.

CARVALHO, A. D. F. et al. Produção sementes de cenoura. In: NASCIMENTO, W. M. (ed.). Curso sobre tecnologia de produção de sementes de hortaliças. Uberlândia: Embrapa Hortaliças, 2014. 19p.

CONTRERAS, S. et al. Acquisition of germination capacity, photosensitivity, and desiccation tolerance in lettuce seeds. Seed Science \& Technology, 36:667-678, 2008.

CORNER, E. J. H. The seeds of dicotyledons. Cambridge University Press, 1976. v.2, $311 \mathrm{p}$.

DELWICHE, L. D.; SLAUGHTER, S. J. The little SAS book: A primer. Cary: SAS Institute, 2003. 268p.

DEMIR, I. Occurrence of hardseedness in relation to seed development in okra (Abelmoschus esculentus (L.) Moench. Plant Varieties and Seeds, 10:7-13, 1997. 
DEMIR, I.; ELLIS, R. H. Changes in seed quality during seed development and maturation in tomato. Seed Science Research, 2:81-87, 1992.

DUTTA, P. C. et al. Lipid bodies in tissue culture, somatic and zygotic embryo of Daucus carota L.: A qualitative and quantitative study. Plant Science, 78(2):259-267, 1991.

GEORGE, R. A. T. Vegetable seed production. Longman: New York, 1985. 318p.

GRAHAM, I. A. Seed storage oil mobilization. Annual Review of Plant Biology, 59:115-142, 2008.

GRAY, D.; STECKEL, R. A. The effects of maturity and drying of carrot seed (Daucus carota $\mathrm{L}$ ) crops on germination. Annals of Applied Biology, 102(2):347-406, 1982.

GRAY, D.; WARD, J. A.; STECKEL, J. R. A. Endosperm and embryo development in Daucus carota L. Journal of Experimental Botany, 35(153):459-465, 1984.

HAMPTON, J. G.; TEKRONY, D. M. Handbook of vigour test methods. 3rd edition. Zurich: ISTA, 1995. 119p.

HARRINGTON, J. F. Seed storage longevity. In: KOZLOWSKY, T. T. (Ed.) Seed biology. New York: Academic Press, 1972. v.3, p.145-245.

HAWTHORN, L. R.; TOOLE, E. H.; TOOLE, V. K. Yield and viability of carrot seeds as affected by position of umbel and time of harvest. Procedings American Society Horticultural Science, 80:401-407, 1962.

JOHANSEN, D. A. Plant microtechnique. London New York: McGraw-Hill, 1940. 523p.

KERMODE, A. R. Approaches to elucidate the basis of desiccation tolerance in seeds. Seed Science Research, 7(1):75-95, 1997.

MAGUIRE, J. D. Speed of germination-aid in selection and evaluation for seedling emergence and vigor. Crop Science, 2(1):176-177, 1962.

MARCOS-FILHO, J. Seed physiology of cultivated plants. Londrina: ABRATES, 2016, 617p.

NASCIMENTO, W. M. Efeito da ordem das umbelas na produção e qualidade de sementes de cenoura. Revista Brasileira de Sementes, 13(2):131-133, 1991.

NASCIMENTO, W. M.; VIEIRA J. V.; ALVARES M. C. Physiological maturity of carrot seeds cV. Alvorada under tropical conditions. Acta Horticulturae, 607:49-51, 2003.
O'BRIEN, T. P.; FEDER, N.; MCCULLY, M. E. Polychromatic staining of plant cell walls by toluidine blue O. Protoplasma, 59:368373, 1964.

PANAYOTOV, N. Heterogeneity of carrot seeds depending on their position on the mother plant. Folia Horticulturae, 22(1):25-30, 2010

PEARSE, A. G. E. Histochemistry, theoretical and applied. 3rd edition, v.2, London: Churchill-Livingstone. 1972.

PERLEBERG, C. S. et al. Uso de fluorescência de clorofila para avaliar a qualidade fisiológica de sementes de cenoura. Informativo Abrates, 11:293, 2001.

ROSS, J. H. E; MURPHY, D. M. Biosynthesis and localization of storage proteins, lesion and lipids during seed development in Coriandrum sativum and other Umbelliferae. Plant Science, 86:59-70, 1992.

RUBATZKY, V. E.; QUIROS C. F.; SIMON P. W. Carrots and related vegetable Umbelliferae. Crop Production Science in Horticulture Series: 10. CABI Publishing. Wallingford. UK, 1999. 304p.

SILVA, G. O.; VIEIRA, J. V.; NASCIMENTO, W. M. Produção de sementes de cenoura. In: NASCIMENTO, W. M. (Ed.). Produção de sementes de hortaliças. v.1. Brasília: Embrapa Hortaliças, 2014. p.117-146.

TEKRONY, D. M.; EGLY, D. B. Accumulating of seed vigour during development and maturation. In: ELLIS, R. H.; BLACK, M.; MURDOCH, A. J. (Ed.) Proceedings of $5^{\text {th }}$ International Workshop on Seeds. Reading, 1995. p.369-384, 1997.

TEKRONY, D. M.; EGLY, D. B.; PHILLIPS, A. D. Effects of field weathering on the viability and on vigor of soybean seed. Agronomy Journal, 72(5):749-753, 1980.

TUCKER, W. G.; GRAY, D. The effects of threshing and conditioning carrot seeds harvested at different times on subsequent seed performance. Journal of Horticultural Science, 61(1):57-70, 1986.

VIDAL, B. C. Acid glycosaminoglycans and endochondral ossification: Microespectrophotometric evaluation and macromolecular orientation. Cellular and Molecular Biology, 22:45-64, 1977.

VIDIGAL, D. S. et al. Alterações fisiológicas e enzimáticas durante a maturação de sementes de pimenta (Capsicum annuum L.). Revista Brasileira de Sementes, 31(2):129-136, 2009.

VIDIGAL, D. S. et al. Changes in seed quality during fruit maturation of sweet pepper. Scientia Agricola, 68(5):535539, 2011.

Ciência e Agrotecnologia 41(2):169-180, Mar/Apr. 2017 
VIDIGAL, D. S. et al. Sweet pepper seed quality and leaprotein activity in relation to fruit maturation and post-harvest storage. Seed Science \& Technology, 37(1):192-201, 2009.
VIGGIANO,J. Produção de sementes de cenoura. In: CASTELLANE, P. D.; NICOLOSI, W. D.; HASHEGAWA, M. Produção de sementes de hortaliças. Jaboticabal: FCAV/FUNEP, 1990. p.61-76. 